\title{
THE DETERMINANTS AND MEASUREMENT OF TRUST IN TAX AUTHORITIES AS A FACTOR INFLUENCING TAX COMPLIANCE BEHAVIOUR
}

\author{
Marina Bornman* \\ University of Johannesburg \\ mbornman@uj.ac.za
}

Received: June 2014

Accepted: September 2015

\begin{abstract}
To trust is to believe that another person will cooperate for your benefit and will not take advantage of you if an opportunity to do so arises. Trust is valued as a relational variable providing the base for voluntary cooperation. This article aims to determine, by reviewing studies on the effect of trust in tax authorities on tax compliance, the determinants, effect and measurement of trust in this context. Findings from a number of studies indicated that trust in tax authorities is positively related to tax compliance, and it was found that perceptions of fairness, treatment by authorities, norms and attitudes, and subjective tax knowledge are the main factors determining trust in tax authorities. However, many studies use very limited descriptors when measuring perceptions of trust in authorities, and it is suggested that a standardised survey instrument could be developed to measure such perceptions.
\end{abstract}

Keywords

Trust, tax compliance, procedural justice, legitimacy, identity, norms and attitudes

*Dr M Bornman is a senior lecturer in the Department of Accountancy, University of Johannesburg, South Africa. 


\section{INTRODUCTION}

Many important economic, social and political behaviours are reliant on trust. To trust is to believe that another person will cooperate for your benefit and will not take advantage of you if an opportunity to do so arises (Ben-Ner \& Halldorsson, 2010). In the context of tax compliance, it implies that taxpayers trust authorities to care about the interest of the social collective and to refrain from self-interest. Likewise, the authorities trust taxpayers to submit honest and accurate information on their tax returns. Feld and Frey (2002) stated that trust by authorities is evident from the way taxpayers are treated, for example, not to be automatically suspected of cheating when a mistake was made on an individual tax return indicates that trust is placed in taxpayers. A climate of trust has been shown to foster voluntary compliance with tax laws (Frey \& Torgler, 2004; Murphy, 2004; Fjeldstad, Schulz-Herzenberg, \& Sjursen, 2012; Levi, Tyler, \& Sacks, 2008; Batrancea \& Nichita, 2013). In studies investigating the effects of trust in authorities on tax compliance, it was found that the concept of trust is not explained in a consistent manner, and the factors that determine trust in authorities appeared to be very narrowly used in empirical research.

Investigating trust as a factor contributing to tax compliance attitudes and behaviour appears to have grown in importance since the late 1990s. An OECD study with 18 participating countries indicated that the majority of countries cited 'trust in government' as an important factor for stimulating compliance (Organisation for $\varepsilon$ conomic Co-operation and Development, 2010). These countries also indicated that they have conducted or commissioned research on the concept of trust. Trust in other taxpayers to pay their taxes is also regarded as a factor that influences tax compliance, but to a lesser extent.

The introduction of the 'slippery slope framework' of tax compliance by Kirchler, Hoelzl, and Wahl (2007) led to more and more scholars aiming to validate the findings of the framework. The slippery slope framework illustrates that a climate of high trust in authorities, as opposed to a climate of high power by authorities, encourages voluntary compliance with tax laws. Studies found to have empirically validated these findings are, amongst others, those done by: Wahl, Kastlunger, and Kirchler (2010); Muelbacher, Kirchler, and Schwarzenberger (2011); Benk and Budak (2012); and Lemoine and Roland-Levy (2013).

This article aims to gain a better understanding of what a climate of high trust means and to identify what the perceived determinants are of such a climate. In addition, the different methods of measuring perceptions of trust in authorities by taxpayers are reviewed to determine their consistency with the factors perceived to be indicators of trust.

\section{BACKGROUND}

The study of tax compliance has seen many contributions from psychology, sociology, and economics since the seminal work of Allingham and Sandmo in 1972. Approaches to predict or explain tax compliance can broadly be placed in two categories: the economic approach and the behavioural approach. The Allingham and Sandmo (1972) model, referred to as the standard economic model, is based on the assumption that taxpayers are self-interested and seek to maximise their outcome by avoiding taxes. Their model is based on four parameters: the probability of evasion detection, punishment of evasion, tax rates and income level. Kirchler 
(2007: 107) states that empirical research has shown that the standard economic model is not working as neoclassical economists had intended, although results are useful for policy purposes.

The higher than expected tax compliance could not be explained by economic theory alone and resulted in researchers considering and analysing new factors of a social nature (Torgler, 2003). Cullis and Lewis (1997) state that tax compliance is more than just a function of opportunity and tax rates, but is also dependent on an individual's willingness to evade or comply, and conclude that values, attitudes, perceptions and morals of economic actors should be included in tax compliance research. This notion is supported by many researchers, as early as Schmölders (19031991) and later Vogel (1974), and many others, making major contributions from a behaviouraleconomic and economic-psychological foundation. See Kirchler (2007) for an overview of research developments in this approach.

In the behavioural approach to tax compliance the concept of trust as a determinant of tax compliance has directly and indirectly been implied in many studies. Kirchler (2007: 202) states that 'trust is a critical factor in understanding the origins of civic engagement, cooperation with authorities and compliance.' Some themes emerged in the behavioural approach to understanding tax compliance, namely tax morale, the psychological contract, motivational postures, and the slippery slope framework. In all of these themes, trust plays a role in the understanding of why people comply with tax laws. The reference to the themes below serves only to emphasise the critical role of trust as a factor influencing tax compliance, and not to give a detailed account of the understanding of tax compliance emerging from the themes.

\subsection{Tax morale and trust}

Tax behaviour has been attributed to a great extent to tax morale (or the intrinsic willingness to comply) (Kornhauser, 2007). Reviewing a large quantity of tax morale literature published since 2001, Kornhauser (2007) shows that studies found tax morale to be affected by (social and personal) norms such as those regarding procedural justice, trust, belief in the legitimacy of the government, reciprocity, altruism, and identification with the group. Similar findings are reported by Torgler and Schaffner (2007), Torgler (2003), and Feld and Frey (2007).

\subsection{The psychological contract and trust}

Feld and Frey (2002: 4) describe the relationship between taxpayers and authorities as an 'implicit or relational contract', now formally called a psychological contract, and they maintain that the psychological contract in part contributes to tax morale. May (2004: 64) observes that 'shared expectations and mutual trust' are central to a sense of obligation that underlie a regulatory contract. The expectation from taxpayers is to be treated respectfully and not to be suspected as tax evaders right from the start (Feld et al., 2002); authorities therefore gain taxpayers' trust with respectful treatment of taxpayers. Feld and Frey (2007) state that respectful treatment is acted out on two levels, namely through fiscal exchange and through procedures.

\subsection{Motivational postures and trust}

Braithwaite (1995) reasons that there are four regulatory postures: resistance and disengagement (associated with non-compliance), and managerial accommodation and capture (associated with compliance). Central to these postures are social bonds which are characterised by shared understandings and goodwill. Braithwaite (1995) states that compliance is brought 
about by shared understandings and goodwill, and these, in turn, are brought about by trust, respect, communication, and interdependency. Her theory on motivational postures developed from these regulatory postures (Braithwaite, 2002) and was converted into the tax compliance model that is still used today by many countries in their approach to understanding and influencing tax compliance (Organisation for Economic Co-operation and Development, 2010).

\subsection{The slippery slope framework of tax compliance and trust}

The most recent contribution to understanding tax compliance comes from Kirchler, Hoelzl, and Wahl (2008), with their slippery slope framework (see FIGURE 1). They explain that tax authorities' orientation towards taxpayers and their style of interaction create a tax climate, driven by trust in authorities on the one hand and power of authorities on the other hand. The climate is characterised either by trust and perceived legitimacy, or by resistance and individual profit maximisation. A climate of trust means that the general opinion of individuals and social groups is one of the benevolence of authorities. A climate of trust fosters cooperation and voluntary compliance, whereas a climate of resistance is characterised by an unwillingness to cooperate and needs a strong display of power by authorities to ensure compliance (enforced compliance).

The framework suggests that high compliance can be maintained only with high levels of trust and power. As soon as trust and power are at intermediate levels, a downward trend may occur, since with trust undermined, a display of power (such as audits and fines) creates even more distrust (Kirchler, 2007).

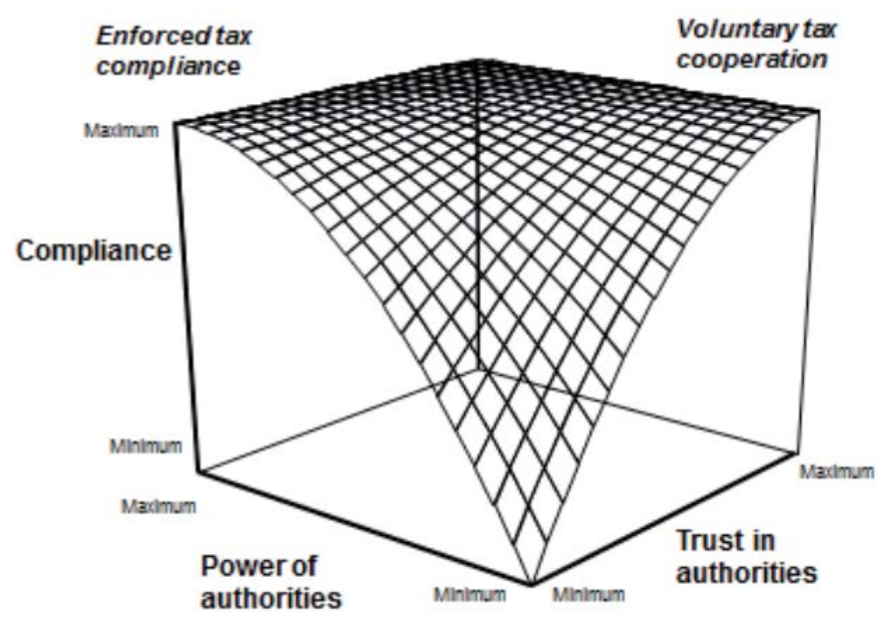

\section{FIGURE 1: The slippery slope framework of tax compliance}

Source: Kirchler, Hoelzl, and Wahl (2008) 


\section{OBJECTIVE}

Given the importance of trust in tax compliance research, the objective of the current investigation is to gain a better understanding of the concept of trust in authorities as a factor influencing tax compliance. Three questions regarding the concept of trust will be investigated.

- What are the factors that contribute to taxpayers' perception of trust in authorities, as measured by researchers using the assumptions of the slippery slope framework, and are there shortcomings in the descriptors used by them?

- What methods are used to measure trust in authorities in empirical studies on tax compliance?

- What are the general findings of these studies with regard to the effect of trust in authorities on tax compliance?

An analysis of previous theoretical and empirical research may lead to a more comprehensive description of the concept of trust to be used in future research on tax compliance, and could assist in selecting appropriate descriptors for the measurement of trust.

\section{THEORETICAL FRAMEWORK}

\subsection{The drivers of trust}

Slemrod (1998) states that it is the behaviour of governments that influences levels of trust. Kornhauser (2007) states that the best way to promote trust is to promote procedural justice, legitimacy, and identification. These three elements will be the premise on which the discussion of the drivers of trust is based.

It is interesting to note that distributive justice is not regarded to have a major impact on trust. Distributive justice refers to how a given pool of resources are distributed so that all social units receive what they are entitled to (Wenzel, 2002). Saad (2010) reports that taxpayers in Malaysia did not perceive distributive fairness (horizontal and vertical fairness) as an important motivation to either comply or not comply. Kirchler (2007) states that no study has revealed negative effects of perceived distributive justice and adds that not all taxpayers may perceive fairness and justice issues as equally relevant. He refers to his earlier study (1998) in which he found that issues of justice and exchange are less important to the self-employed than to whitecollar workers and civil servants. Wenzel (2002) also reports inconsistent findings from several studies with regard to taxpayers' perception of the fairness of their share in tax-based benefits, and Taylor (2002) found that it is the extent to which authorities are perceived to be representative of taxpayers that determine their legitimacy, not fairness in distribution. Taylor (2002) also found that when distributive outcomes were perceived as unfair, taxpayers focused on the unfair procedures that were directly relevant to producing those outcomes.

The concepts of procedural justice, legitimacy, and identification influence one another apart from influencing trust, as will be shown in the discussion below. FIGURE 2 illustrates the drivers of trust and their mutual effect on one another. 


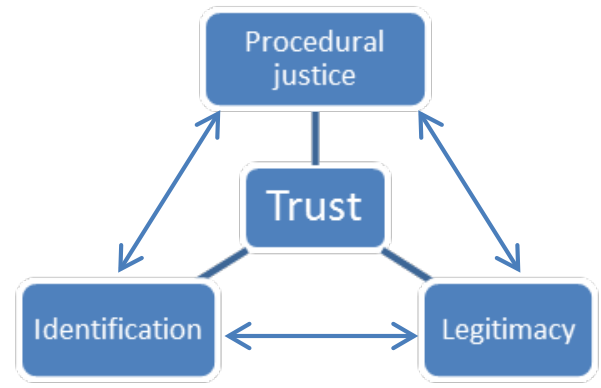

\section{FIGURE 2: THE DRIVERS OF TRUST}

Source: Author's deduction

Tyler (2006a) supports the interaction of these factors that shapes compliance with the law and summarises:

(a) legitimacy is a distinct judgement that shapes rule-related behaviour;

(b) people use ethical judgements about the fairness of procedures (procedural justice) to determine the legitimacy of authorities; and

(c) people's motivation to cooperate with legal authorities is rooted in social relationships (identification) which strengthen social values of legitimacy and morality.

\subsubsection{Legitimacy}

The concept of trust in authorities is sometimes difficult to distinguish from perceptions of public support, confidence and allegiance. Tyler (1990:28) states that these terms are often considered under the heading 'trust in government'. According to Tyler (1990), this type of trust stems from a perception of legitimacy. Murphy (2005) describes legitimacy as the acceptance of an authority by regulatees based on the perception that authorities do their job well and are entitled to be obeyed. Tyler (2006b) adds that legitimacy is a quality attributed to an authority by a population. He also states that indicators of legitimacy are general feelings of responsibility and obligation to obey the law and legal authorities by citizens. Bowers and Robinson (2012) describe legal authorities as legitimate when they act impartially, honestly, transparently, respectfully, ethically, and equitably.

The concepts of legitimacy, procedural justice, and morality as a social value are closely intertwined. Procedural justice is widely hypothesised to be an antecedent of legitimacy (Murphy 2005). According to Bowers and Robinson (2012), legitimacy can be measured by the quality of decision making by legal authorities and also by how defendants are treated. They further state that legitimate procedures should provide opportunities for error correction and for interested parties to be heard. Fallon (2005, as cited by Tyler (2006a)) notes that legitimacy can also be based on consistency with moral values.

Two more determinants of legitimacy are representativeness and retributive fairness. Taylor (2002) states that authorities who are perceived by a group or society as representative of their values are seen as legitimate. Retributive fairness, relating to the perception of fairness in the 
application of punishment by authorities when the rules are broken, also plays a role in attributing legitimacy to authorities (Organisation for Economic Co-operation and Development, 2010).

The extent of legitimacy attributed to an authority is therefore dependent on how members of the public perceive the actions of the authority as fair, respectful and honest, and in congruence with their own social judgements and morality. According to Kirchler (2007), a trusting climate between taxpayers and tax authorities is likely to be related to perceived legitimacy of tax authorities.

\subsubsection{Procedural justice}

Procedural justice refers to the fairness of the processes of a resource allocation or distribution; it thus pertains to the ways, modes and procedures followed when interacting with taxpayers (Wenzel, 2002). Van Dijke and Verboon (2010) state that people are often unsure whether authorities can be trusted not to abuse their power. In such situations, people use their perception and experience of fairness during interaction with authorities as a heuristic guide to decide the extent of trust they will place in authorities. Van den Bos, Wilke, and Lind (1998) state that people who do not have information about an authority's trustworthiness react more positively toward the outcomes of the authority's decisions if the authority is using fair as opposed to unfair procedures. De Cremer and Tyler (2007) also confirm this finding, but warn that trust cannot be substituted by procedural fairness - in fact, respondents relied more on the cue of procedural fairness when trust was present. Van Dijke and Verboon (2010) explain that people expect fair procedures to lead to fair outcomes, hence increasing their willingness to trust.

Leventhal (1980) regards procedures as fair when they are consistent, accurate, free of errors, representative, ethical and correctable. Wenzel (2002: 54) distinguishes between four issues in this interaction, namely: (a) the quality of the treatment by tax authorities, (b) the degree to which taxpayers have a say, (c) the extent and quality of information provided by tax authorities, and (d) compliance and administration cost. The fairness of these interactions can be interpreted by taxpayers on an individual, group and societal level. TABLE 1 provides examples of what constitutes fairness in the different interactions according to Wenzel (2002).

Murphy (2004) states that people who feel they have been treated fairly by an organisation will be more likely to trust that organisation and accept its decisions. This view is supported by Levi, et al. (2008), who found considerable evidence of a link between the extent of procedural justice and trust and confidence in authority and citizens' perceptions. In a survey conducted amongst tax avoiders, Murphy (2004) illustrates that taxpayers who experienced poor treatment from a tax authority as a result of their infractions (innocent or otherwise) displayed a decrease in trust in the authority, which could ultimately result in resistance towards the tax authority.

Kornhauser (2007) remarks that 'procedural justice builds trust, loyalty, identification, and commitment', ensuring the maintaining of compliance even during occasional negative interaction with authorities. Verboon and Van Dijke (2011) also report that for sanctions to be effective, authorities should ensure that they treat their followers in a fair manner. 
TABLE 1: Procedural justice in taxation

\begin{tabular}{|c|c|c|c|}
\hline & Individual Level & Group level & Societal level \\
\hline $\begin{array}{l}\text { Interaction } \\
\text { treatment }\end{array}$ & $\begin{array}{l}\text { Respect for the } \\
\text { individual; } \\
\text { consistent treatment } \\
\text { relative to other } \\
\text { individuals }\end{array}$ & $\begin{array}{l}\text { Respect for the group; } \\
\text { consistent treatment } \\
\text { relative to other } \\
\text { groups }\end{array}$ & $\begin{array}{l}\text { Rights for taxpayers } \\
\text { and service standards }\end{array}$ \\
\hline $\begin{array}{l}\text { Degree to which } \\
\text { taxpayers have a say }\end{array}$ & $\begin{array}{l}\text { Consultation of } \\
\text { individual }\end{array}$ & $\begin{array}{l}\text { Consultation and } \\
\text { representation of the } \\
\text { group }\end{array}$ & $\begin{array}{l}\text { Consultation of } \\
\text { taxpayers in general; } \\
\text { democratic structures }\end{array}$ \\
\hline $\begin{array}{l}\text { Extent and quality of } \\
\text { information provided } \\
\text { by tax authorities }\end{array}$ & $\begin{array}{l}\text { Explanations and } \\
\text { justifications for } \\
\text { decisions affecting } \\
\text { the individual }\end{array}$ & $\begin{array}{l}\text { Explanations and } \\
\text { justifications for } \\
\text { decisions affecting } \\
\text { the group }\end{array}$ & $\begin{array}{l}\text { Transparency; } \\
\text { presentation in media }\end{array}$ \\
\hline Cost of complying & $\begin{array}{l}\text { Efficiency; } \\
\text { service vs. cost for } \\
\text { the individual }\end{array}$ & $\begin{array}{l}\text { Efficiency; } \\
\text { service vs. cost for the } \\
\text { group }\end{array}$ & $\begin{array}{l}\text { Administration and } \\
\text { compliance costs; } \\
\text { complexity of the tax } \\
\text { system }\end{array}$ \\
\hline
\end{tabular}

Source: Wenzel, 2002:55

\subsubsection{Identification}

Identifying with a group or society can change an individual's orientation from being selfinterested to collectively oriented (Kornhauser, 2007), meaning that concerns about what is right/good/fair for all group members become the dominant focus. Braithwaite (1995) states that trustworthy actions by government generate social trust through establishing a social bond or shared identity. Thus, perceptions of trustworthy actions by a group or society form the social norm of trust held by that group. Wenzel (2004) found that social norms have a stronger impact when there is stronger identification with the group of people to whom the norms are attributed. If trust is then regarded as a social norm, then stronger identity with the social group will strengthen the social norm of trust. Ashraf, Bohnet and Plankov (2006), Castelfranchi and Falcone (2001), and Ben-Ner and Halldorsson (2010) confirm the notion of trust as a social norm, and Wenzel (2002) shows that the procedural fairness of the tax authority is particularly influential in stimulating tax compliance among citizens who strongly identify with the notion.

Identification also happens on a higher level. Tax authorities can be perceived as representative of taxpayers through embodying the values and ideals of being fair, neutral and trustworthy. Identification with authorities, or including authorities within one's self-categorisation, leads to perception of authorities to be more legitimate, fair and trustworthy, because they are perceived as representative of the self (Taylor, 2002). The less representative tax authorities are perceived to be, the less legitimacy and trustworthiness they are attributed. Alm and Torgler (2011) state that a tax administration must recognise that it can erode the ethics of taxpayers by its own decisions. 


\subsection{Qualities of trust}

Kirchler, Hofmann, and Gangl (2012) distinguish two qualities of trust, derived from the work of Castelfranchi and Falcone. Castelfranchi and Falcone's (2010) main claim is that trust as a mental attitude is either goal-based or belief-based. Kirchler et al. (2012) name it reason-based trust and implicit trust. Reason-based trust rests upon a rational decision to trust another person based on whether the trustee and trustor have the same goals, whether the trustor depends on the trustee, whether the trustee is perceived as competent, willing, and harmless, and whether there are external conditions that foster or hinder the achievement of the goal. Implicit trust, on the other hand, is an automatic and emotional reaction. This automatic reaction originates from social relations that occur between people, and conditioned learning processes and memory. It appears that trust derived from procedural justice shows similarities with reason-based trust, whereas legitimacy and identity are more automatic and therefore similar to implicit trust.

\subsection{Trust in government versus trust in tax authorities}

How does trust in general government influence trust in the tax authority, especially in situations where people feel incidences of corruption and waste in government are high? Although it does not answer the question, a finding from Balliet, Mulder, and Van Lange (2011) pertains to such a situation: trust matters the most when there is a larger conflict of interest. When it is most difficult to trust, this is when trust is most needed to encourage cooperation. They report that trust, which is a form of belief about others' benevolent motives, informs behaviour during situations of conflict.

Van Dijke and Verboon (2010) suggest that it is important to differentiate between trust in the specific authority that is enacting the procedures (e.g., the tax office), and trust in general authorities (i.e., not directed at the specific authority that enacts the procedures). They cite other research to show that fairly enacted procedures improve trust in the enacting authority. Their study amongst employed Dutch citizens, using an online questionnaire, indicated that particularly citizens with low general trust in authorities are influenced positively by the fair interaction with the tax authority in their decision whether to comply or not. In other words, low trust in general authority makes citizens attend more closely to the fairness with which they are treated by the tax office.

Taylor (2002) argues that tax revenue authorities are designated by governments to collect revenue on behalf of governments. Therefore, if governments are perceived as representative, then the role of tax authorities should be perceived as legitimate. In a study on Australian taxpayers, she investigates the degree to which government was perceived as representative of self and the degree to which the Australian Tax Office (ATO) was perceived as representative of self. She finds a moderately strong correlation, implying that perceived legitimacy of government is related to perceived legitimacy of the ATO.

Studies have shown that corruption has a negative effect on tax morale. In a study on transition countries, Torgler (2004) observes a high correlation between the degree of tax morale and the perceived size of corruption. In a recent study covering 29 countries in sub-Saharan Africa it is reported that perceived corruption among tax authorities remains significant, and evidence suggests that these perceptions undermine public commitment to the integrity of the tax system and increase the likelihood of non-compliance (Aiko and Logan, 2014). More than one-third of the respondents ( $35 \%$ ) say that 'most' or 'all' tax officials are corrupt, and another $39 \%$ think that at least some of them are. 
Generalised trust in authorities may depend on the behaviour of a number of different branches of the government, as perceived by the public and portrayed by the media (Van Dijke \& Verboon, 2010). The extent to which trust generalises between different types of authorities is not well documented and provides scope for future research.

\subsection{A climate of trust}

Kirchler, Hofmann, and Gangl (2012) describe the determinants of the tax climate as transparency of tax law and procedures, attitudes towards tax issues, norms regarding taxes, and fairness considerations in the context of taxation. Thus, according to Kirchler (2007), a climate of trust will ensue if interaction with authorities are trustworthy, if citizens understand the law, if taxes are perceived to be distributed fairly and procedures to be just, and if citizens hold positive attitudes towards the government and have developed favourable personal and social norms.

Kirchler et al.'s (2008) understanding of a climate of trust therefore includes all the drivers of trust as discussed in the preceding sections. A comparison is made in TABLE 2. The only element not addressed in 'drivers of trust' is that of personal norms. Ashraf, Bohnet and Plankov (2006) remark that internalised norms could induce people to trust and be trustworthy - despite the fact that trust often does not 'pay'. In a dictator game experiment run across three nations, they establish that trust is based on expectations of trustworthiness and on unconditional kindness. Ben-Ner and Halldorsson (2010) report similar findings. It could therefore be said that a personal norm of unconditional kindness can be added as a driver of trust.

\section{TABLE 2: The comparison of the drivers of trust and a climate of trust}

\begin{tabular}{ll}
\hline \multicolumn{1}{c}{ The drivers of trust } & \multicolumn{1}{c}{ A climate of trust } \\
\hline Legitimacy & - Taxes perceived to be distributed fairly \\
& - Citizens understand the law \\
& (Kirchler, Niemirowski, \& Wearing (2006) \\
& stated that tax knowledge and perceived \\
& legitimacy are positively related) \\
& - Citizens hold positive attitudes towards \\
& government \\
- Interaction with authorities is trustworthy & - Favourable social norms (implying that the \\
Identity & individual has internalised the social norms \\
& because of strong identification with the \\
& community) \\
& - Personal norms - unconditional kindness
\end{tabular}

Source: Author's deduction

In summary, it appears that trust in authorities is experienced by taxpayers through perceptions of legitimacy, procedural justice, and identification with a group. In the analysis of studies that follows in section 6, these three drivers will be used to determine how the perception of trust is elicited from respondents. Personal norms will not be included as a separate driver, since it appears that the distinction between personally held norms and social norms are seldom explicit. 


\section{METHOD}

A qualitative approach was employed in analysing a collection of studies that had investigated the effect of trust on tax compliance, specifically using the assumptions of the slippery slope framework. Studies were analysed to determine what the researchers' understanding of trust is and what methods were used to measure perceptions of trust from the respondents. Studies were purposively chosen to include controlled computer experiments and surveys, and only studies that provided details of the questionnaire or instructions used to elicit perceptions of trust were included. The sample also included studies from different countries, and respondents ranging from real taxpayers to students.

Three indicators were used to define how trust is measured: procedural justice (treatment of taxpayers), legitimacy and identity. Treatment indicators are related to perceived treatment of taxpayers by tax authorities, as indicated by questions such as: the tax office treats taxpayers in a respectful manner. Legitimacy indicators relate to how taxpayers see tax authorities (e.g. as fair, trustworthy). Identity indicators relate to any reference to the values or cohesion of the community and the inclusion of the self.

\section{RESULTS AND DISCUSSION}

In TABLE 3, a number of studies relating to the effect of trust on tax compliance behaviour are analysed with regard to the descriptors used by the researchers to measure respondents' degree of trust. In the same table, the methods employed are also listed. TABLE 4 lists the typical questions asked in the surveys to elicit perceptions on trust, categorised as treatment-, legitimacy- or identity-related. A discussion will follow after the tables.

\section{TABLE 3: Analysis of studies relating to trust and tax compliance behaviour}

\begin{tabular}{|c|c|c|c|c|}
\hline $\begin{array}{c}\text { Author/s, year } \\
\text { Country }\end{array}$ & $\begin{array}{l}\text { Descriptors used } \\
\text { to measure trust }\end{array}$ & $\begin{array}{l}\text { Research } \\
\text { method }\end{array}$ & $\begin{array}{l}\text { Number and } \\
\text { type of } \\
\text { participants }\end{array}$ & $\begin{array}{l}\text { Findings regarding trust } \\
\text { and voluntary compliance }\end{array}$ \\
\hline $\begin{array}{l}\text { Lemoine \& Roland- } \\
\text { Levy, } 2013 \\
\text { France }\end{array}$ & $\begin{array}{l}\text { Treatment } \\
\text { Legitimacy } \\
\text { Identity } \\
\text { (only one } \\
\text { question on } \\
\text { each) }\end{array}$ & $\begin{array}{l}\text { Scenario-based } \\
\text { questionnaire } \\
\text { (self- } \\
\text { employment } \\
\text { scenario) }\end{array}$ & $\begin{array}{l}320 \text { university } \\
\text { students }\end{array}$ & $\begin{array}{l}\text { Trustworthy description of } \\
\text { authorities leads to more } \\
\text { voluntary tax compliance, } \\
\text { than when confronted with } \\
\text { an untrustworthy } \\
\text { description (no effect of } \\
\text { the manipulation of trust } \\
\text { on enforced tax } \\
\text { compliance) }\end{array}$ \\
\hline $\begin{array}{l}\text { Kastlunger, Lozza, } \\
\text { Kirchler, \& } \\
\text { Schabmann, (2013) } \\
\text { Italy }\end{array}$ & $\begin{array}{l}\text { Treatment } \\
\text { Legitimacy }\end{array}$ & $\begin{array}{l}\text { Online and } \\
\text { paper-based } \\
\text { questionnaire }\end{array}$ & $\begin{array}{l}389 \text { self- } \\
\text { employed } \\
\text { taxpayers } \\
\text { and } \\
\text { entrepreneurs }\end{array}$ & $\begin{array}{l}\text { Trust is positively related } \\
\text { to voluntary tax } \\
\text { compliance }\end{array}$ \\
\hline $\begin{array}{l}\text { Kochler, Batrancea, } \\
\text { Nichita, Pantya, } \\
\text { Belianin, \& Kirchler } \\
\text { (2013) }\end{array}$ & $\begin{array}{l}\text { Treatment * } \\
\text { Legitimacy }\end{array}$ & $\begin{array}{l}\text { Paper-based } \\
\text { questionnaire } \\
\text { with different } \\
\text { scenarios }\end{array}$ & 1319 students & $\begin{array}{l}\text { Higher voluntary } \\
\text { compliance was observed } \\
\text { in the conditions of high } \\
\text { trust. }\end{array}$ \\
\hline
\end{tabular}




\begin{tabular}{|c|c|c|c|c|}
\hline $\begin{array}{c}\text { Author/s, year } \\
\text { Country }\end{array}$ & $\begin{array}{l}\text { Descriptors used } \\
\text { to measure trust }\end{array}$ & $\begin{array}{l}\text { Research } \\
\text { method }\end{array}$ & $\begin{array}{c}\text { Number and } \\
\text { type of } \\
\text { participants }\end{array}$ & $\begin{array}{l}\text { Findings regarding trust } \\
\text { and voluntary compliance }\end{array}$ \\
\hline \multicolumn{5}{|l|}{$\begin{array}{l}\text { Austria, Hungary, } \\
\text { Romania, Russia }\end{array}$} \\
\hline $\begin{array}{l}\text { Muelbacher, } \\
\text { Kirchler, \& } \\
\text { Schwarzenberger } \\
\text { (2011) } \\
\text { Austria, Czech } \\
\text { Republic \& United } \\
\text { Kingdom }\end{array}$ & $\begin{array}{l}\text { Treatment * } \\
\text { Legitimacy }\end{array}$ & $\begin{array}{l}\text { Online } \\
\text { questionnaires }\end{array}$ & $\begin{array}{l}3071 \\
\text { taxpayers }\end{array}$ & $\begin{array}{l}\text { Voluntary cooperation } \\
\text { depends primarily on trust } \\
\text { (perceived power of } \\
\text { authorities and trust in } \\
\text { authorities jointly } \\
\text { positively influence } \\
\text { voluntary compliance, } \\
\text { although the influence of } \\
\text { power is rather low) }\end{array}$ \\
\hline $\begin{array}{l}\text { Wahl, Kastlunger, \& } \\
\text { Kirchler (2010) } \\
\text { (experiment 1) } \\
\text { Various countries } \\
\text { in Europe }\end{array}$ & $\begin{array}{l}\text { Treatment } \\
\text { Legitimacy }\end{array}$ & $\begin{array}{l}\text { Computer-aided } \\
\text { tax filing } \\
\text { experiment with } \\
\text { a high-trust } \\
\text { condition and a } \\
\text { low-trust } \\
\text { condition }\end{array}$ & 120 students & $\begin{array}{l}\text { 1) Voluntary compliance is } \\
\text { highest when authorities } \\
\text { are trustworthy and } \\
\text { powerful compared to } \\
\text { when authorities are } \\
\text { trustworthy and powerless. } \\
\text { 2) Participants are } \\
\text { generally more voluntarily } \\
\text { compliant with trustworthy } \\
\text { authorities than with } \\
\text { untrustworthy authorities. }\end{array}$ \\
\hline $\begin{array}{l}\text { Wahl, Kastlunger, \& } \\
\text { Kirchler (2010) } \\
\text { (experiment 2) } \\
\text { Various countries } \\
\text { in Europe }\end{array}$ & $\begin{array}{l}\text { Treatment * } \\
\text { Legitimacy }\end{array}$ & $\begin{array}{l}\text { Online } \\
\text { questionnaire } \\
\text { Scenario-based }\end{array}$ & $\begin{array}{l}186 \text { Self- } \\
\text { employed } \\
\text { taxpayers }\end{array}$ & $\begin{array}{l}\text { 1) It was found that trust } \\
\text { in authorities and the } \\
\text { power of authorities } \\
\text { differently affect the } \\
\text { motivation to comply on a } \\
\text { voluntary or an enforced } \\
\text { basis. } \\
\text { 2) Participants were more } \\
\text { voluntarily compliant when } \\
\text { authorities were } \\
\text { trustworthy than when } \\
\text { authorities were } \\
\text { untrustworthy. }\end{array}$ \\
\hline $\begin{array}{l}\text { Benk \& Budak } \\
(2012) \\
\text { Turkey }\end{array}$ & $\begin{array}{l}\text { Treatment } \\
\text { Legitimacy }\end{array}$ & $\begin{array}{l}\text { Survey: } \\
\text { Questionnaires } \\
\text { using Likert- } \\
\text { type scale }\end{array}$ & $\begin{array}{l}300 \text { self- } \\
\text { employed } \\
\text { taxpayers }\end{array}$ & $\begin{array}{l}\text { 1) Trust in authorities is a } \\
\text { significant but small } \\
\text { predictor of voluntary tax } \\
\text { cooperation } \\
\text { 2) Trust in authorities has } \\
\text { no significant influence on } \\
\text { enforced compliance }\end{array}$ \\
\hline $\begin{array}{l}\text { Ruiu \& Lisi (2011) } \\
\text { World-wide }\end{array}$ & Legitimacy & $\begin{array}{l}\text { Cross-section } \\
\text { analysis } \\
\text { data from the } \\
\text { World Value } \\
\text { Surveys (fifth } \\
\text { wave) }\end{array}$ & & $\begin{array}{l}\text { 1) Trust in tax authorities } \\
\text { exerts a larger effect on } \\
\text { shadow economy than law } \\
\text { enforcement. } \\
\text { 2) A decrease in the level } \\
\text { of vertical trust leads to a }\end{array}$ \\
\hline
\end{tabular}




\begin{tabular}{|c|c|c|c|c|}
\hline $\begin{array}{c}\text { Author/s, year } \\
\text { Country }\end{array}$ & $\begin{array}{l}\text { Descriptors used } \\
\text { to measure trust }\end{array}$ & $\begin{array}{l}\text { Research } \\
\text { method }\end{array}$ & $\begin{array}{l}\text { Number and } \\
\text { type of } \\
\text { participants }\end{array}$ & $\begin{array}{l}\text { Findings regarding trust } \\
\text { and voluntary compliance }\end{array}$ \\
\hline & & & & $\begin{array}{l}\text { decrease in the level of tax } \\
\text { morale (relation is } \\
\text { statistically very } \\
\text { significant). }\end{array}$ \\
\hline
\end{tabular}

Source: Author's deduction

* Items marked with * meant that the same descriptors were used in the survey instrument, namely the scale developed by Wahl et al. (2010)

TABLE 4: Typical questions or prompts used in surveys to elicit respondents' perception of trust

\begin{tabular}{|c|c|c|}
\hline Treatment factors & Legitimacy Factors & Identity factors \\
\hline $\begin{array}{l}\text { The Tax Office treats } \\
\text { taxpayers in a respectful } \\
\text { manner. } \\
\text { - The governmental } \\
\text { authorities in Country X } \\
\text { act fairly towards their } \\
\text { citizens. } \\
\text { - Tax authorities are } \\
\text { treating citizens correctly. }\end{array}$ & $\begin{array}{l}\text { - The Tax Office is fair in } \\
\text { collecting tax. } \\
\text { - The Tax Office is } \\
\text { trustworthy in Country X } \\
\text { - The governmental } \\
\text { institutions of Country X } \\
\text { act upon their citizens' } \\
\text { interests. } \\
\text { - The government supports } \\
\text { its citizens. } \\
\text { Tax authorities seem } \\
\text { reliable. } \\
\text { Tell me how much } \\
\text { confidence you have in: } \\
\text { a) Police, b) Justice } \\
\text { system, c) Parliament }\end{array}$ & $\begin{array}{l}\text { - In Country } X \text { the interests } \\
\text { of a few are considered } \\
\text { stronger than the } \\
\text { interests of the } \\
\text { community. }\end{array}$ \\
\hline
\end{tabular}

Source: Author's deduction

Of the eight studies analysed, only one study used elements of all three determinants of trust, but then in a very limited manner (with only one question pertaining to each determinant). Most studies assessed perceptions of trust on the basis of respondents' perception of the legitimacy of authorities and the perception of fair treatment only. Treatment factors were mainly measured by a single question, in most cases: 'The tax authority treats taxpayers in a respectful manner.'

It is suggested that the eliciting of perceptions of trust is done in a very narrow manner. Wenzel (2002) argues that procedural justice relates to more than just the quality of the treatment by tax authorities, but also the degree to which taxpayers have a say, the extent and quality of information provided by tax authorities, and compliance and administration cost. No questions in the surveys analysed suggested any of these factors in addition to being treated in a respectful manner.

Legitimacy, as a quality attributed to an authority based on perceptions that the authority does its job well, is entitled to be obeyed, and is representative of taxpayers, was also measured very 
narrowly. Also, no descriptors referring to tax knowledge and retributive fairness as indicators of legitimacy were included in any study.

\subsection{Methods and instruments used to measure trust}

Many studies used a scenario to create a fictitious country with a high trust and a low trust condition, describing a high trust condition as one where tax authorities are highly trustworthy, service-oriented, interested in supporting citizens, and little tax money is embezzled by politicians. In the low trust condition tax authorities were characterised as highly untrustworthy, not service-oriented, not interested in supporting citizens, with a lot of tax money being embezzled by politicians (see e.g. Kochler, et al., 2013). These conditions were then manipulated and respondents' perceptions on trust, power and other variables were asked. Kirchler and Wahl (2010) emphasised the importance of taking the tax climate into account when gauging perspectives on trust and other variables and their effect on tax compliance. Prinz, Muehlbacher, and Kirchler (2014) state that laboratory experiments are probably the most easy to use to manipulate power and trust effects using the scenario technique, and surveys are another method that allows measuring taxpayers' perceptions with manipulation of conditions. All the studies analysed therefore used appropriate methods.

As analyses were based mainly on self-reports, they may well have elicited socially desirable responses. Benk and Budak (2012) state that self-reports may tend to comply with tax law rather than reflect actual tax behaviour. However, Kirchler and Wahl (2010) argue that by using fictitious cases or scenarios for assessing tax evasion the problem of social desirability could be reduced.

\subsection{Effect of trust on tax compliance}

The studies were unanimous in their findings that trust is positively related to voluntary tax compliance. Most studies reported that higher voluntary compliance was observed in conditions of high trust.

\section{CONCLUSION}

A tax climate, as suggested by the slippery slope framework, is created by the tax authority's orientation towards taxpayers, and taxpayers' attitudes and perception of authorities. The slippery slope framework proposes that a climate of high trust is conducive to voluntary tax compliance, and many empirical studies validate this proposition. A climate of trust is characterised by legitimacy, procedural justice and the extent to which taxpayers identify with their country and other groups with positive social norms towards tax compliance. From the comparison of the 'drivers of trust' with the 'climate of trust' illustrated in TABLE 2 , it is suggested that personal norms could be specified as an additional driver of trust.

Several studies empirically validating the propositions of the slippery slope framework were analysed in the present article (see TABLE 3). These studies were analysed to determine the scope and nature of their conceptualisation of trust. It was found that, in general, perceptions on trust by respondents are measured using limited descriptors. The concept of trust is therefore very narrowly described and could include a greater variety of descriptors. It is suggested that the following additional descriptors could be included for future measurement of trust in tax authorities: 
- Procedural justice: perceptions on the degree to which taxpayers have a say, the quality of information provided by tax authorities, and ease and cost of complying can be included. Given the fact that much communication between tax authorities and taxpayers happens online, indicators such as response time, personalised responses, and ease of communication could also be indicators of perceptions of fair treatment.

- Legitimacy: descriptors referring to tax knowledge and perceptions on retributive fairness (perception of fairness in the application of punishment by authorities when the rules are broken).

- Identity: the strength of respondents' identification with the community, and extent to which they subscribe to the values of the community.

- Personal norms: the extent to which respondents perceive themselves as 'unconditionally kind'.

The methods or instruments used by the studies were mainly scenario-based surveys which allow for manipulation of trust and power conditions and are regarded as most suitable in achieving their objectives.

A limitation of the present study is that although a large variety of empirical studies were analysed, not all studies pertaining to trust and tax compliance were included in the study. Only studies using the assumptions of the slippery slope framework were included, and of these only a purposive sample of studies found published in reputable academic journals was used. Further, only studies that provided access to the questions or scenarios used could be included.

It is noted that the extent to which trust generalises between different types of authorities is not well documented and provides scope for further research. For example, does a general perception by taxpayers that government is corrupt extend to their perception of tax authorities, and does that influence trust in tax authorities?

It is suggested that a standardised survey instrument could be developed to measure perceptions of trust in tax authorities containing elements of legitimacy, procedural fairness, and identity or social norm factors.

\section{LIST OF REFERENCES}

Aiko, R., \& Logan, C. (2014, March 5). Africa's Willing Taxpayers Thwarted by Opaque Tax Systems, Corruption. Afrobarometer. Available:

http://www.afrobarometer.org/files/documents/policy_brief/ab_r5_policypaperno7.pdf. (Accesses 10 May 2014).

Allingham, M. G., \& Sandmo, A. (1972, August). Income Tax Evasion: A Theoretical Analysis. Journal of Public Economics, 1, pp. 323-338.

Alm, J., \& Torgler, B. (2011). Do Ethics Matter? Tax Compliance and Morality. Journal of Business Ethics, 101, 635-651.

Ashraf, N., Bohnet, I., \& Plankov, N. (2006). Decomposing Trust and Trustworthiness. Experimental Economics, 9, 193-208.

Balliet, D., Mulder, L. b., \& Van Lange, P. A. (2011). Reward, Punishment, and Cooperation: A MetaAnalysis. Psychological Bulletin, 137(4), 594-615. 
Batrancea, L., \& Nichita, R. (2013). Tax Non-compliance Behavior in the Light of Tax Law Complexity and the Relationship between Authorities and Taxpayers. Annals of the Alexandru loan Cuza University - Economics, 59(1), 97-106.

Benk, S., \& Budak, T. (2012). Power and trust as determinants of voluntary versus enforced tax compliance: Empirical evidence for the slippery slope framework from Turkey. African Journal of Business Management, 6(4), 1499-1505.

Ben-Ner, A., \& Halldorsson, F. (2010). Trusting and trustworthiness: What are they, how to measure them, and what affects them. Journal of Economic Psychology, 31, 64-79.

Bowers, J., \& Robinson, P. H. (2012). Perceptions of Fairness and Justice: The shared Aims and Occasional Conflicts of Legitimacy and Moral Credibility. Wake Forest Law review, 47, 211-284.

Braithwaite, V. (1995). Games of Engagement: Postures within the Regulatory Community. Law \& Policy, 17(3), 225-255.

Braithwaite, V. (2002). Taxing Democracy. Aldershot: Ashgate Publishing Ltd.

Castelfranchi, C., \& Falcone, R. (2001). Social trust: A Cognitive Approach. In C. Castelfranchi, \& T. Yao-Hua, Trust and Deception in Virtual Societies (pp. 55-90). Dordrecht: Springer Science+Business Media.

Cullis, J. G., \& Lewis, A. (1997). "Why people pay taxes" From a conventional economic model to a model of social convention. Journal of Economic Psychology, 18, 305-321.

De Cremer, D., \& Tyler, T. R. (2007). The Effects of Trust in Authority and Procedural Fairness on Cooperation. Journal of Applied Psychology, 92(3), 639-649.

Feld, L. P., \& Frey, B. S. (2002). Trust Breeds Trust: How Taxpayers Are Treated. University of Zurich. Zurich: Institute for Empirical Research in Economics. (Working paper no.98).

Feld, L. P., \& Frey, B. S. (2007, January). Tax Compliance as the Result of a Psychological Tax Contract: The Role of Incentives and Responsive Regulation. Law \& Policy, 29(1), pp. 102-120.

Fjeldstad, 0.-H., Schulz-Herzenberg, C., \& Sjursen, I. H. (2012). Peoples' view of taxation in Africa: A review of research and determinants of tax compliance. CMI Working Paper 2012: 7, International Centre for Tax and Development.

Frey, B. S., \& Torgler, B. (2004). Taxation and Conditional Cooperation. Basel: Centre for Research in Economics, Management and the Arts. (Working paper no. 2004 - 20).

Kastlunger, B., Lozza, E., Kirchler, E., \& Schabmann, A. (2013). Powerful authorities and trusting citizens: The Slippery Slope Framework and tax compliance in Italy. Journal of Economic Psychology, $34,36-45$.

Kirchler, E. (2007). The Economic Psychology of Tax Behaviour. New York: Cambridge University Press.

Kirchler, E., \& Wahl, I. (2010). Tax compliance inventory TAX-I: Designing an inventory for surveys of tax compliance. Journal of Economic Psychology, 31, 331-346.

Kirchler, E., Hoelzl, E., \& Wahl, I. (2008). Enforced versus Voluntary Tax Compliance: The Slippery Slope Framework. Journal of Economic Psychology, 210-225.

Kirchler, E., Hofmann, $\varepsilon ., \&$ Gangl, K. (2012). From Mistrusting Taxpayers to Trusting Citizens Empirical Evidence and Further Development of the Slippery Slope Framework. Economic psychology in the modern world: collected papers, pp. 125-146. Available: 
http://epsy.fa.ru/sbornik_statej_ehkonomicheskaja_psikhologija.pdf\#page=125. (Accessed 22 March 2014).

Kirchler, E., Niemirowski, A., \& Wearing, A. (2006). Shared subjective views, intent to cooperate and tax compliance: Similarities between Australian taxpayers and tax officers. Journal of Economic Psychology, 27, 502-517.

Kochler, C., Batrancea, L., Nichita, A., Pantya, J., Belianin, A., \& Kirchler, દ. (2013). Trust and power as determinants of tax compliance: Testing the assumptions of the slippery slope framework in Austria, Hungary, Romania and Russia. Journal of Economic Psychology, 34, 169-180.

Kornhauser, M. (2007). Normative and cognitive aspects of tax compliance: Literature review and recommendation for the IRS regarding individual taxpayers. New York: IRS. (2007 Annual Report to Congress 138) Available: http//www.irs.gov/advocate/article/0,id=177301.html. (Accessed 18 February 2014).

Lemoine, J., \& Roland-Levy, C. (2013). Are taxpayers, who pay their taxes, all cooperative citizens? Citizenship Teaching \& Learning, 8(2), 195-213.

Leventhal, G. (1980). What should be done with equity theory? New approaches to the study of fairness in social relationships. In K. Gergen, M. Greenberg, \& R. Willis, Social Exchange: Advances in theory and research (pp. 27-55). Neork: Plenum.

Levi, M., Tyler, T., \& Sacks, A. (2008). The Reasons for Compliance with Law. US Studies Centre. Sydney. (Working paper August 2009). Available:

http://ussc.edu.au/s/media/docs/publications/0908_levi_compliance.pdf. (Accessed 12 February 2014).

May, P.J. (2004). Compliance Motivations: Affirmative and Negative Bases. Law \& Society Review, 38(1), 41-68.

Muelbacher, S., Kirchler, E., \& Schwarzenberger, H. (2011). Voluntary versus enforced tax compliance: empirical evidence from the "slippery slope" framework. European Journal of Law and Economics, 32, 89-97.

Murphy, K. (2004). The Role of Trust in Nurturing Compliance: A Study of Accused Tax Avoiders. Law and Human Behavior, 28(2), 187-209.

Murphy, K. (2005). Regulating More Effectively: The Relationship between Procedural Justice, Legitimacy, and Tax Non-compliance. Journal of Law and Society, 32(4), 562-589.

Organisation for Economic Co-operation and Development. (2010, November). Understanding and Influencing Taxpayers' Compliance Behaviour. Available:

http://www.oecd.org/tax/administration/46274793.pdf. (Accessed 23 0ctober 2012).

Prinz, A., Muehlbacher, S., \& Kirchler, $\varepsilon$. (2014). The slippery slope framework on tax compliance: An attempt to formalisation. Journal of Economic Psychology, 40, 20-34.

Ruiu, G., \& Lisi, G. (2011). Tax Morale, Slippery-Slope Framework and Tax Compliance: A Cross-section Analysis. Dipartimento di Scienze Economiche. Cassino (FR): Università degli Studi di Cassino. (Working paper no. 5/2011).

Saad, N. (2010). Fairness Perceptions and Compliance Behaviour: The Case of Salaried Taxpayers in Malaysia after Implementation of the Self-Assessment System. eJournal of Tax Research, 8(1), 3265.

Schmölders, G. (1959). Fiscal Psychology: A new Branch of Public Finance. National Tax Journal, 12(4), 340-345. 
Slemrod, J. (1998, September). On Voluntary Compliance, Voluntary Taxes and Social Capital. National Tax Journal, 51(3), 485-491.

Taylor, N. (2002). Understanding Taxpayer Attitudes through Understanding Taxpayer Identities. In V. Braithwaite, Taxing Democracy (pp. 71-92). Aldershot: Ashgate.

Torgler, B. (2003, July). TAX MORALE: THEORY AND EMPIRICAL ANALYSIS OF TAX COMPLIANCE. Doctoral thesis. Basel: Universitat Basel.

Torgler, B. (2004). Tax Morale, Trust and Corruption: Empirical Evidence from Transition Countries. Basel: Center for Research in Economics, Management and the Arts.

Torgler, B., \& Schaffner, M. (2007, November). Causes and Consequences of Tax Morale: An Empirical Investigation. Crema Working Paper no 2007-11. Basel, Switzerland: Center for Research in Economics, Management and the Arts.

Tyler, T. (1990). Why People Obey the Law. Chelsea, Michigan: Yale University Press.

Tyler, T. (2006b). Restorative Justice and Procedural Justice: Dealing with Rule Breaking. Journal of Social Issues, 62(2), 307-326.

Tyler, T. R. (2006a). Why People Obey the Law. Princeton, New Jersey: Princeton University Press.

Van den Bos, K., Wilke, H. A., \& Lind, E. A. (1998). When Do We Need Procedural Fairness? The Role of Trust in Authority. Journal of Personality and Social Psychology, 75(6), 1449-1458.

Van Dijke, M., \& Verboon, P. (2010). Trust in authorities as a boundary condition to procedural fairness. Journal of Economic Psychology, 31, 80-91.

Verboon, P., \& Van Dijke, M. (2011). When do severe sanctions enhance compliance? The role of procedural fairness. Journal of Economic Psychology, 32, 120-130.

Vogel, J. (1974). Taxation and public opinion in Sweden: An interpretation of recent survey data. National Tax Journal, 27 (1), 499-513.

Wahl, I., Kastlunger, B., \& Kirchler, દ. (2010, October). Trust in Authorities and Power to Enforce Tax Compliance: An empirical Analysis of the "Slippery Slope Framework". Law \& Policy, 32(4), 383-406.

Wenzel, M. (2002). Tax Compliance and the Psychology of Justice: Mapping the Field. In V. Braithwaite, Taxing Democracy (pp. 41-70). Aldershot: Ashgate.

Wenzel, M. (2004). An analysis of norm processes in tax compliance. Journal of Economic Psychology, $25,213-228$. 